\title{
Emergent and re-emergent parasites in HIV-infected children: immunological and socio-environmental conditions that are involved in the transmission of Giardia spp. and Cryptosporidium spp.
}

\author{
Brisa Maria Fregonesi[1], Meire Nikaido Suzuki[1], Carolina Sampaio Machado ${ }^{[1]}$, \\ Karina Aparecida de Abreu Tonani ${ }^{[1]}$, Ana Paula Morais Fernandes ${ }^{[2]}$, \\ Aline Aparecida Monroe ${ }^{[2]}$, Maria Célia Cervi ${ }^{[3]}$ and Susana Segura-Muñoz ${ }^{[1]}$
}

\begin{abstract}
[1]. Laboratório de Ecotoxicologia e Parasitologia Ambiental, Escola de Enfermagem de Ribeirão Preto, Universidade de São Paulo, Ribeirão Preto, São Paulo, Brasil. [2]. Departamento de Enfermagem Geral e Especializada, Escola de Enfermagem de Ribeirão Preto, Universidade de São Paulo, Ribeirão Preto, São Paulo, Brasil. [3]. Departamento de Puericultura e Pediatria, Faculdade de Medicina de Ribeirão Preto, Universidade de São Paulo, Ribeirão Preto, São Paulo, Brasil.
\end{abstract}

\begin{abstract}
Introduction: Emergent and re-emergent waterborne protozoans have become a worldwide public health problem, especially among vulnerable groups. Methods: This cross-sectional study evaluated $17 \mathrm{HIV}$-infected children and their families. Results: A high (76.5\%) percentage of parasite-infected children was observed, even among children with CD4 ${ }^{+} \mathrm{T}$-cell counts of $>200$ cells $/ \mathrm{mm}^{3}$. Giardia spp., Cryptosporidium spp. and Cyclospora spp. were observed in $41.2 \%$ of these children. Low income, poor hygiene practices, and co-infection in domestic, peridomestic and scholastic environments were significant sources of these intestinal infections. Conclusions: Early diagnosis, timely treatment, and socio-educational interventions may improve the health conditions of this vulnerable population.
\end{abstract}

Keywords: Emerging/re-emerging parasites. Childhood. HIV/AIDS.

Since the 1980 s, waterborne protozoan parasites have emerged and re-emerged and became a worldwide public health problem, especially among vulnerable population groups ${ }^{(1)(2)}$. For example, children with a suppressed immune system are more susceptible to infections that are caused by opportunistic agents, especially when their $\mathrm{CD} 4^{+} \mathrm{T}$-lymphocyte counts are $<200$ cells $/ \mathrm{mm}^{3}$ or $15 \%{ }^{(1)}(3)$, and are especially vulnerable to clinical complications that are caused by intestinal parasites. Acute diarrhea and persistent vomiting can lead to severe dehydration and poor nutrient absorption, which can delay the child's growth and development, and can lead to hospitalization for an unstable clinical condition or death in severe cases ${ }^{(2)}$.

Different factors may contribute to intestinal parasite transmission, including children's hand-to-mouth habits, interpersonal contact in daycare facilities, sanitation status, poor personal and/or food hygiene, and contact with parasite-infected

Corresponding author: Profa. Susana Segura-Muñoz. Laboratório de Ecotoxicologia e Parasitologia Ambiental/Dept ${ }^{\circ}$ Materno Infantil e Saúde Pública/EERP/USP. Av. Bandeirantes 3900, 14040-902 Ribeirão Preto, São Paulo, Brasil.

Phone: 55 16 3315-0530; Fax: 5516 3315-0518.

e-mail: susis@eerp.usp.br

Received 8 April 2015

Accepted 27 May 2015 people and/or animals ${ }^{(2)(4)(5)}$. However, there is little systematic data regarding the parasitological, immunological, and socioenvironmental conditions of human immunodeficiency virus (HIV)-infected children, or regarding these factors' relationships with have emerging and re-emerging intestinal protozoans, which exhibit high persistence and infectivity in vulnerable populations. Therefore, the present study aimed to assess the presence of intestinal parasites in HIV-infected children, with an emphasis on Giardia spp. and Cryptosporidium spp. These data may help identify the correlation between intestinal parasitic infections and the patient's immunological condition, verify the intra-family/ household co-infection status for these patients, and characterize the socio-environmental conditions that may be involved in the transmission of emergent/re-emergent intestinal parasites.

This quantitative cross-sectional cohort study was performed during March-September 2013, in a specialized unit for HIVinfected adults and children at a public hospital in the northeast region of the State of São Paulo, Brazil. We included all HIV1 -infected patients who visited the outpatient clinic, were $\leq 13$ years old, provided a stool sample, and were living in Ribeirão Preto, State of São Paulo, Brazil. We identified 24 children, although only 17 children (3-12 years old; 9 girls and 8 boys) were followed for the full 6 months. The intestinal parasites and immunological and socio-environmental conditions of these patients were evaluated. 
The children's family members were also asked to participate in order to evaluate their intra-family/household co-infection status. Twenty family members of $10 \mathrm{HIV}$-infected children agreed to participate, and were evaluated for intestinal parasites. These family members were 3-65 years old, and included 13 women and 8 men.

We collected 2-3 stool samples on alternating days and analyzed these samples at the Laboratory of Ecotoxicology and Environmental Parasitology (University of São Paulo, Ribeirão Preto College of Nursing). A total of 47 stool samples from HIV-infected children and 57 samples from family/household members were analyzed. The modified Ziehl-Neelsen technique was used to detect and identify intestinal coccidian parasites, including Cryptosporidium spp., Cystoisospora spp., and Cyclospora spp. ${ }^{(6)}$. The sedimentation/Coproplus ${ }^{\circledR}$ technique (NL Comércio Exterior Ltda, São Paulo, Brazil) was used to identify Giardia spp. and other noncoccidian parasites ${ }^{(7)}$. Immunoenzymatic assays [Giardia Stool Antigen Detection Microwell enzyme-linked immunosorbent assay (ELISA) and Cryptosporidium Stool Antigen Detection Microwell ELISA; IVD Research, USA] were used to confirm Giardia spp. and Cryptosporidium $\mathrm{spp}^{(2)}$. Macroscopic analyses of all samples were also performed to verify their diarrheal characteristics, including a soft consistency, mucus, and liquefaction of the stools.

Data regarding the patients' $\mathrm{CD} 4^{+} \mathrm{T}$-lymphocyte counts (cells $/ \mathrm{mm}^{3}$ and percentage), viral load (copies $/ \mathrm{mL}$ and logadjusted value), adherence to antiretroviral treatment (ART), and previous parasitological conditions were collected from their clinical records. A structured questionnaire was validated and used to collect data regarding the patients' socio-environmental conditions: family's monthly income, sanitation status, personal and food hygiene habits, water-based recreational activities, and contact with animals and other children.

Descriptive analyses were performed for the parasitological, immunological, and socio-environmental data. Fisher's exact test was used to identify potential correlations between the immunological characteristics and parasitic infection status (via a p-value of $<0.05$ ), using Statistical Package for the Social Sciences (SPSS) software (version 22.0; SPSS Inc. Chicago, IL). Ethical approval was obtained from the University of São Paulo at Ribeirão Preto College of Nursing (referee report no. 159.935). Participation was voluntary, and informed consent/ assent was obtained from participants and/or their guardian.

The socio-environmental conditions of the children are shown in Table 1. Highlights from these data include the following: $88.2 \%$ of the patients' families had a low monthly income (up to 3 times the Brazilian minimum wage ${ }^{(8)}$ ); $100 \%$ of the families were supplied with safe public drinking water, sewage collection, and treatment systems; $47.1 \%$ of the children did not wash their hands before meals; and all the children had frequent contact with other children and pets in the domestic, peridomestic, and scholastic environments.

The identified parasites, CD $4^{+}$T-lymphocyte counts, and viral loads are presented in Table $\mathbf{2}$ according to patient age and sex. The presence of parasites was more frequent

TABLE 1 - Socio-environmental profile of HIV-infected children in a tertiary hospital. Ribeirão Preto, State of São Paulo, Brazil, 2013.

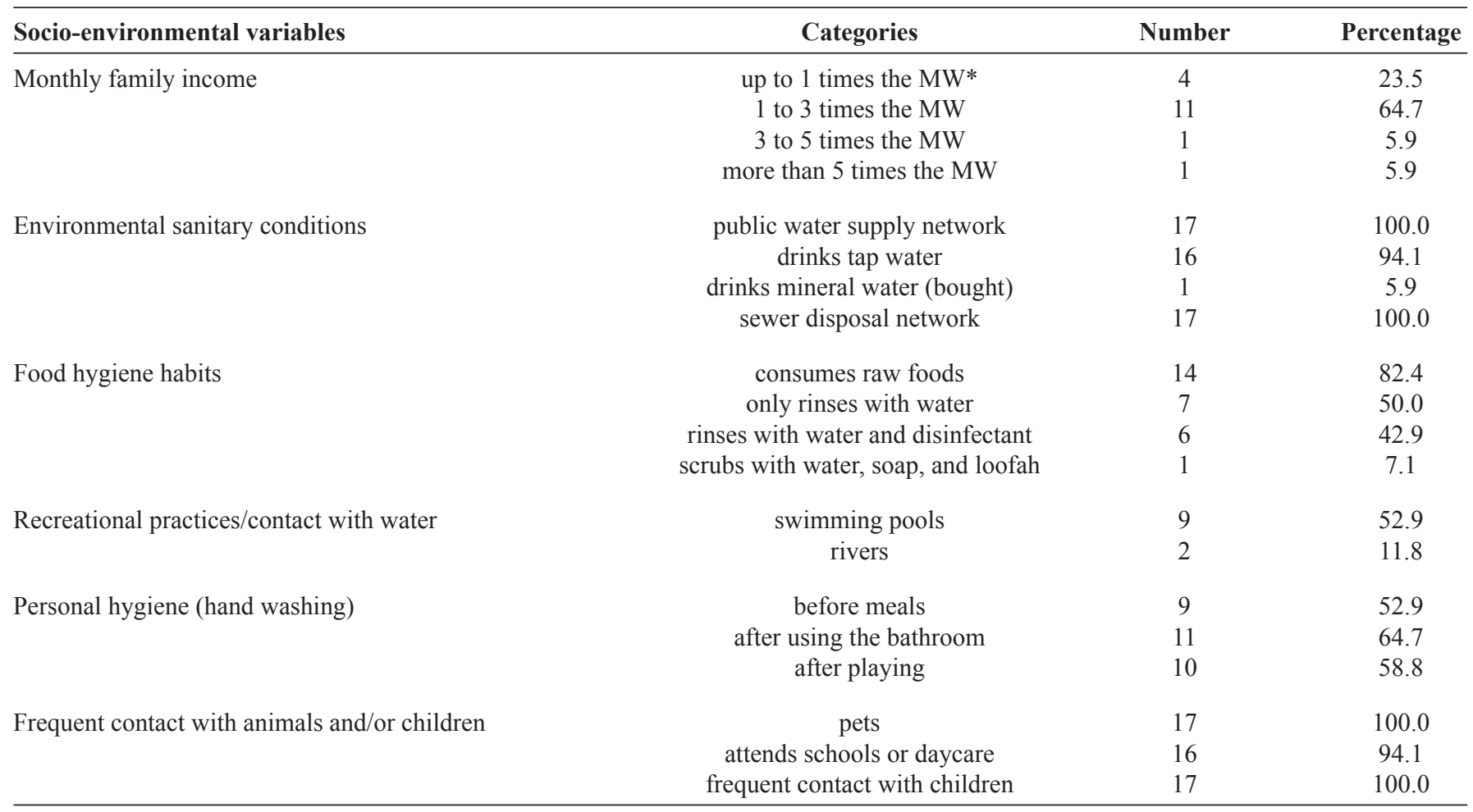

HIV: human immunodeficiency virus; MW: Brazilian minimum wage/person/month. *MW corresponded to R\$678.00 (approximately US\$283.7) in 2013 ${ }^{(8)}$. 
TABLE 2 - Parasites, CD4+ T-cells, and viral load among HIV-infected children. Ribeirão Preto, State of São Paulo, Brazil, 2013.

\begin{tabular}{|c|c|c|c|c|c|c|}
\hline \multicolumn{3}{|c|}{ Social variables } & $\begin{array}{c}\text { Main variable } \\
\text { parasites } \\
\text { (pathogenic and commensal) }\end{array}$ & \multicolumn{3}{|c|}{ Clinical variables } \\
\hline 2 & 7 & $\mathrm{~F}$ & absent & $\geq 500$ & ND & $+/-$ \\
\hline 3 & 12 & $\mathrm{~F}$ & absent & $200-499$ & $53(1.724)$ & $+/-$ \\
\hline 5 & 11 & F & absent & $200-499$ & $67,884(4.832)$ & $+/-$ \\
\hline 6 & 12 & F & Giardia spp. & $\geq 500$ & $62(1.792)$ & $+/-$ \\
\hline 7 & 3 & M & Entamoeba coli & $\geq 500$ & ND & $+/-$ \\
\hline 11 & 7 & M & Entamoeba coli & $\geq 500$ & $52(1.716)$ & $+/-$ \\
\hline 12 & 9 & M & Entamoeba coli & $\geq 500$ & ND & $+/-$ \\
\hline 13 & 11 & F & Cryptosporidium spp., Giardia spp., Entamoeba coli & $\geq 500$ & $36,833(4.566)$ & $+/-$ \\
\hline 14 & 12 & M & Cryptosporidium spp. & $\geq 500$ & ND & $+/-$ \\
\hline 15 & 6 & M & Cryptosporidium spp., Giardia spp. & $\geq 500$ & $14,605(4.165)$ & $+/-$ \\
\hline 16 & 8 & M & Entamoeba coli & $\geq 500$ & ND & $+/-$ \\
\hline 17 & 12 & $\mathrm{~F}$ & Entamoeba coli & $\geq 500$ & ND & $+1-$ \\
\hline
\end{tabular}

CD4 $^{+}$: cluster of differentiation $4^{+}$; HIV: human immunodeficiency virus; ART: antiretroviral therapy; ND: not detected (below the limit of detection); F: female; M: male. Clinical variables: CD4+ T-cells [immunocompetent: $\geq 500$ cells $/ \mathrm{mm}^{3}$, mild immunodeficiency: $200-499$ cells $/ \mathrm{mm}^{3}$, severe immunodeficiency: $<200$ cells $\left./ \mathrm{mm}^{3}(3)\right]$.

in boys $(100 \%)$, compared to that in girls $(55.5 \%)$. The frequencies of monoparasitism, biparasitism, and triparasitism were $52.9 \%, 11.8 \%$, and $11.8 \%$, respectively. We observed pathogenic infections (Giardia spp., Cryptosporidium spp., and/ or Cyclospora spp.) in $41.2 \%$ of the children, and $35.3 \%$ of the children presented with only a commensal parasite (Entamoeba coli). Entamoeba coli exhibited the highest prevalence (47\%), followed by Giardia spp. (35.3\%), Cryptosporidium spp. (23.5\%), and Cyclospora spp. (5.9\%). Cystoisospora spp. was not found in the analyzed samples. All the patients were receiving ART and were immunocompetent $(82.4 \%)$ or only had mild immunodeficiency (17.6\%), which may explain the absence of gastrointestinal symptoms despite the presence of parasitic infections. No statistically significant correlations were observed between their immunological condition and the presence of parasites $(p>0.05)$. Medical records revealed that $41.2 \%$ of the patients had already been hospitalized at least once due to diarrhea, and that $28.6 \%$ were infected by Giardia spp. Only traditional stool tests were performed for $64.7 \%$ of the children (Faust and Modified Hoffman Tests), and testing for Cryptosporidium spp. and Cystoisospora spp. was only performed for $17.6 \%$ of the children; all test results were negative.
The parasite infections from the patients' family members organized according to age and relationship are shown in Table 3. At least one parasite was identified in $70 \%$ of the patients' family members. Giardia spp. and Entamoeba coli were the most frequent parasites (50\% each), and were identified as independent infections or co-infections with other parasites, including Cryptosporidium spp., Cyclospora spp., Strongyloides stercoralis, and Enterobius vermicularis. In $60 \%$ of the families, at least two individuals from the same household presented with the same parasite(s), independent of HIV-infection status.

Monitoring HIV-infected children who are undergoing continuous ART in specialized units can ensure that acute parasitic infections remain asymptomatic in these children ${ }^{(1)}$. Furthermore, continuous contact between these children and parasites and/or environmental exposure to asymptomatic parasite genotypes may cause asymptomatic infections ${ }^{(9)}$. However, when the immunological system is suppressed or ART is discontinued, these patients' clinical conditions can deteriorate, and they can experience acute diarrhea and dehydration that requires hospitalization ${ }^{(1)}$.

It is known that Giardia spp., Cryptosporidium spp., Cyclospora spp., and Entamoeba coli have human and animal enteric origins, and are transmitted directly or indirectly via the 
TABLE 3 - Parasites in family members living with HIV-infected children. Ribeirão Preto, State of São Paulo, Brazil, 2013.

\begin{tabular}{|c|c|c|}
\hline Relationship & Age & Parasites \\
\hline $\begin{array}{l}\text { Child } 3 \\
\text { brother } \\
\text { brother } \\
\text { father* }\end{array}$ & $\begin{array}{l}13 \\
14 \\
21 \\
42\end{array}$ & $\begin{array}{c}\text { negative } \\
\text { Giardia } \text { spp. } \\
\text { negative } \\
\text { Giardia } \text { spp., Strongyloides stercoralis }\end{array}$ \\
\hline $\begin{array}{l}\text { Child } 4 \\
\text { aunt }\end{array}$ & $\begin{array}{l}12 \\
32\end{array}$ & $\begin{array}{c}\text { Giardia spp., Cyclospora spp. } \\
\text { negative }\end{array}$ \\
\hline $\begin{array}{l}\text { Child } 6 \\
\text { cousin } \\
\text { cousin } \\
\text { cousin }\end{array}$ & $\begin{array}{c}13 \\
4 \\
8 \\
9\end{array}$ & $\begin{array}{l}\text { Giardia spp. } \\
\text { Giardia spp., Entamoeba coli } \\
\text { Giardia spp., Entamoeba coli, Cryptosporidium spp., Enterobius vermiculares } \\
\text { Giardia spp., Entamoeba coli }\end{array}$ \\
\hline $\begin{array}{l}\text { Child } 9 \\
\text { brother } \\
\text { brother } \\
\text { mother* } \\
\text { father* }\end{array}$ & $\begin{array}{c}9 \\
10 \\
11 \\
35 \\
65\end{array}$ & $\begin{array}{l}\text { Giardia spp., Entamoeba coli, Cryptosporidium spp. } \\
\text { Giardia spp. Entamoeba coli } \\
\text { Giardia spp. Entamoeba coli } \\
\text { Giardia } \text { spp., Entamoeba coli } \\
\text { Giardia } \text { spp., Entamoeba coli }\end{array}$ \\
\hline $\begin{array}{l}\text { Child } 10 \\
\text { sister } \\
\text { adoptive mother }\end{array}$ & $\begin{array}{c}13 \\
4 \\
32\end{array}$ & $\begin{array}{l}\text { Entamoeba coli } \\
\text { Entamoeba coli } \\
\text { Entamoeba coli }\end{array}$ \\
\hline
\end{tabular}

HIV: human immunodeficiency virus. *HIV-infected family member.

fecal-oral route ${ }^{(2)}$. Therefore, families who live in poor sanitary conditions and exhibit inadequate hygiene habits are believed to be undergoing constant infection and re-infection by those protozoans $^{(5)}$. However, Ribeirão Preto's public water supply comes from the Guarani Aquifer, which is an underground source of high-quality water ${ }^{(10)}$. Furthermore, all the families in this study had access to sewage disposal, which indicates that sanitation status did not strongly affect their parasitic infections.

Despite the existence of an adequate sanitation system, poor hygiene practices among the children and their family members may have led to the infections during meal preparation and/or consumption, via contaminated foods. For example, researchers have found Giardia spp., Cryptosporidium spp., and Cyclospora spp. in leafy vegetables that were produced in the United States, Canada, and Mexico ${ }^{(11)}$. Furthermore, these protozoans are remarkably resistant to common disinfectants and may survive in raw foods ${ }^{(2)(11)}$.
Although they were not frequent activities, swimming in pools or rivers may also have contributed to the infections via the accidental ingestion of contaminated water. Giardia spp., Cryptosporidium spp., and Cyclospora spp. have been found throughout the world in recreational water, including chlorinated water, because they are resistant to adverse environmental conditions $^{(12)(13)}$. Moreover, the identified parasites have a high zoonotic potential, with the capacity to develop in human and animal hosts ${ }^{(2)}$. Different Brazilian regional studies have also reported the presence of Giardia spp., Cryptosporidium spp., and Cyclospora spp. in dogs and cats ${ }^{(13)(14)}$. Giardia spp. and Cryptosporidium spp. cysts are in their infective form in pets' feces, and it is possible that children develop parasitic infections via this route. Therefore, frequent contact with pets and/or their feces may also be related to the high frequencies of parasitic infections among these children. 
Another socio-environmental factor that may have contributed to the parasitic infections was personal hygiene. For example, the patients did not wash their hands before meals $(47.1 \%)$, after using the bathroom $(35.3 \%)$, or after playing $(41.2 \%)$. Therefore, it is essential to increase the awareness of caregivers and HIV-infected children regarding preventive measures that can control intestinal parasitic infections, and to promote activities that encourage the adoption of healthy personal and food hygiene habits. Health education efforts may be facilitated via the incorporation of various technologies, as well as inter-sector commitment and responsibility to cooperation within the healthcare system, especially among primary healthcare and educational services.

The high prevalence of Giardia spp. and Entamoeba coli in the patients may be explained by the relatively easy inter-personal transmission of these parasites, as $94.1 \%$ of the patients were attending school or daycare. Giardia is one of the most common intestinal parasites that affect Brazilian children, especially children who attend these institutions, with a prevalence of $8-50 \% \%^{(5)}$ (7). Similarly, Cryptosporidium is a significant protozoa that is disseminated in schools and daycare facilities $^{(2)}$, which explains its presence in $23.5 \%$ of the HIV-infected patients. This prevalence is higher than that of Cryptosporidium spp. infections among healthy children in other Brazilian cities $(\leq 15.5 \%)^{(4)}$. However, few studies have attempted to identify Cyclospora spp. in children who attend daycare facilities, which may be due to the low likelihood of inter-personal transmission ${ }^{(2)}$.

Contact with cohabitating family members may also influence intestinal parasitic infections among HIV-infected children. For example, contact with parasite-infected family members or cohabitants is an important risk among HIV-infected individuals $^{(2)(3)}$. The similarities among the identified parasites in the patients' family members reaffirm the fact that interpersonal contact during daily living increases the risk of parasitic infection ${ }^{(15)}$. Therefore, cohabitants or family members should also be considered in the processes of diagnosis and treatment.

Despite the high frequency of intestinal parasitic infections among HIV-infected children in this study, the absence of symptoms hinders any investigation regarding potentially pathogenic emerging and re-emerging agents, due to neglect and underreporting. Therefore, the introduction of routine diagnostic techniques to detect emergent parasites in HIV-infected patients can help facilitate an early diagnosis. Furthermore, parasite control in asymptomatic individuals is relevant because the intermittent elimination of feces can lead to environmental contamination.

Treatment with parasite-specific medications should be started immediately after an HIV-infected child is diagnosed with a potentially pathogenic parasite infection, in order to avoid recurrent infection symptoms. However, there is currently no effective and specific treatment for Cryptosporidium spp., although the Food and Drug Administration has approved nitazoxanide for treating cryptosporidiosis in individuals with healthy immune systems. Unfortunately, the efficacy of this medication in immunosuppressed individuals is not clearly established and requires further study ${ }^{(2)}$. Therefore, permanent monitoring of the immune response, with antiretroviral and antiparasitic treatment adherence, is important for preventing the clinical symptoms of cryptosporidiosis ${ }^{(2)}$.

In conclusion, this study demonstrates that it is necessary to strengthen the clinical management of individual patients, as well as collective and environmental management practices. Improvements in health education strategies have the potential to transform lifestyles, especially among vulnerable population segments, such as HIV-infected children and their families. Furthermore, future studies should analyze the genotypes of regional parasite strains and isolates that are found in HIVinfected children and their families.

\section{CONFLICT OF INTEREST}

The authors declare that there is no conflict of interest.

\section{FINANCIAL SUPPORT}

\section{Coordenação de Aperfeiçoamento de Pessoal de Nivel} Superior (CAPES).

\section{REFERENCES}

1. Adamu H, Wegayehu T, Petros B. High prevalence of diarrhoegenic intestinal parasite infections among non-ART HIV patients in Fitche Hospital, Ethiopia. PLoS One 2013; 8:e72634.

2. Centers for Disease Control and Prevention (CDC). Parasites (Internet). Atlanta: CDC. (Cited 2015 Jan 07). Available from: http://www.cdc. gov/parasites

3. Ministério da Saúde. Protocolo clínico e diretrizes terapêuticas para manejo da infecção pelo HIV em crianças e adolescentes (Internet). Brasília: Ministério da Saúde; 2014 (update 2014 Dec 05; cited 2015 Feb 08). Available at: http://www.aids.gov.br/sites/default/files/ anexos/publicacao/2014/55939/08_05_2014_protocolo_pediatrico pdf_36225.pdf

4. Mascarini LM, Donalísio MR. Giardíase e criptosporidiose em crianças institucionalizadas em creches no estado de São Paulo. Rev Soc Bras Med Trop 2006; 39:577-579.

5. Santos CK, Grama DF, Limongi JE, Costa FC, Couto TR, Soares RM, et al. Epidemiological, parasitological and molecular aspects of Giardia duodenalis infection in children attending public daycare centers in southeastern Brazil. Trans R Soc Trop Med Hyg 2012; 106:473-479.

6. Henriksen S, Pohlenz J. Staining Cryptosporidia by a modified ZiehlNeelsen technique. Acta Vet Scand 1981; 22:594-596.

7. Garcia JGD, Simões MJS, Alvarenga VLS. Avaliação de diferentes métodos no diagnóstico laboratorial de Giardia lamblia. Rev Cienc Farm Basica Apl 2006; 27:253-258.

8. Ministério do Trabalho e Emprego. Salário Mínimo 2013 (Internet) Brasília: Ministério do Trabalho e Emprego; 2013. (Cited 2015 Jan 08). Available at: http://portal.mte.gov.br/sal_min/

9. Roka M, Goñi P, Rubio E, Clavel A. Prevalence of intestinal parasites in HIV-positive patients on the island of Bioko, Equatorial Guinea: its relation to sanitary conditions and socioeconomic factors. Sci Total Environ 2012; 432:404-411.

10. Departamento de água e esgoto de Ribeirão Preto (DAERP). Esgoto (Internet). Ribeirão Preto: SP. Departamento de água e esgoto 
de Ribeirão Preto; (Cited 2015 Jan 08). Available at: http://www. ribeiraopreto.sp.gov.br/daerp

11. Dixon B, Parrington L, Cook A, Pollari F, Farber J. Detection of Cyclospora, Cryptosporidium, and Giardia in Ready-to-Eat Packaged Leafy Greens in Ontario, Canada. J Food Protect 2013; 76:307-313.

12. Doménech-Sánchez A, Olea F, Berrocal CI. Infections related to recreational waters. Enferm Infecc Microbiol Clin 2008; 13:32-37.

13. Sherchan JB, Sherpa K, Tandukar S, Cross JH, Gajadhar A, Shrechand JB. Infection of Cyclospora cayetanensis in diarrhoeal children of Nepal. J Nepal Paediatr Soc 2010; 30:23-30.
14. Sotiriadou I, Pantchev N, Gassmann D, Karanis P. Molecular identification of Giardia and Cryptosporidium from dogs and cats. Parasite 2013; 20:8.

15. Anuar TS, Al-Mekhlafi HM, Ghani MK, Osman E, Yasin AM, Nordin A, et al. Giardiasis among different tribes of Orang Asli in Malaysia: highlighting the presence of other family members infected with Giardia intestinalis as a main risk factor. Int J Parasitol 2012; 42: 871-880. 